\title{
Height and hourly variations in the concentration of airborne pollen grains and fungal spores in Sosnowiec (Poland)
}

\author{
Katarzyna Dąbrowska-Zapart, Tadeusz Niedźwiedź \\ Faculty of Natural Sciences, Institute of Earth Sciences, University of Silesia in Katowice, Poland
}

\begin{abstract}
:
The aim of the work was to compare the qualitative and quantitative composition of aeroplankton in Sosnowiec (Poland) at three heights. The research was conducted on July $3^{\text {rd }}, 4^{\text {th }}$ and $5^{\text {th }}$, 2018 with the help of three Burkard spore traps: one stationary and two portable ones. The analyses were carried out at an altitude of $83 \mathrm{~m}, 15 \mathrm{~m}$ and at the ground level. Aerobiological data was recorded every hour and the collected pollen grains and fungal spores were determined later on. The relationships between individual meteorological conditions and different features of the alder pollen season were determined using Spearman's rank correlation coefficients. The research has shown that the greatest fluctuations in the daily pollen count occurred at the lowest measuring point, i.e. at the ground level. The largest part of the determined palynomorphs were fungal spores, the most numerous of which was Cladosporium, followed by Alternaria, Epicoccum and Botrytis. Statistical analysis showed that the highest concentrations of fungal spores and plant pollen grains were influenced by wind speed, maximum gust of wind and solar radiation.
\end{abstract}

Key words: sampler height, daily pollen count, fungal spore, plant pollen, meteorological conditions, Poland

U nderstanding the variability in the concentration of pollen grains and fungal spores, which varies with sampler height, is an important issue in the study of spatial distribution patterns. In the case of urban areas, this is important in the context of the occurrence of allergenic pollen and spores in multi-storey and highrise buildings. This article presents preliminary results concerning the vertical distribution of pollen grains and fungal spores in the northern part of Sosnowiec, characterized by loose distribution of blocks of flats. It is generally assumed that aeroplankton concentration decreases logarithmically along with the increase in height [1-4], because pollen grains and fungal spores, as small particles, are subject to the laws of gravity and usually settle at ground level. However, convective and mechanical turbulence prevents the complete sedimen- tation of aeroplankton and often causes pollen, spores and other particles to rise. Mandrioli et al. [5] outlined two processes by which the vertical transport of particles may take place. The first is turbulent transport by air currents, which regulates the vertical mixing of particles in the atmosphere, and the second is severe convective storms, which can also transport the particles upwards. The problem of aeroplankton distribution in urban areas seems to be complicated by the presence of many buildings, often high, which disturb the natural flow of air. Research in the US and London shows that sometimes fungal spore and pollen grain concentration increases with height, thus being significantly lower at street level than at roof level $[6,7]$.

Sosnowiec is a town in the south of Poland in the eastern part of the Silesian Upland (fig. 1). Despite 
the significant concentration of residential and industrial buildings, Sosnowiec is an area where various habitats are covered by a large number of vascular plants (tracheophyte) belonging to many botanical families. According to Jędrzejko [8], the total area occupied by greenbelt in the urban area is approximately $24.7 \%$.

In the area of the Silesian Upland, where Sosnowiec is located, the influence of various air masses intersect, which is why the climate is characterized by considerable variability and irregularity of the course of climatic elements. Sosnowiec is located in the temperate-transitional climate zone between the oceanic and the continental zones. The weather throughout the year $(65 \%)$ is influenced by polar maritime air flowing in from the Atlantic Ocean. The average annual temperature is at the level of $9.2^{\circ} \mathrm{C}$; the warmest month is July $\left(19.5^{\circ} \mathrm{C}\right)$, and the coldest month is January $\left(-1.2^{\circ} \mathrm{C}\right)$. The average annual precipitation is $735 \mathrm{~mm}$. Snow falls for an average of 50 days a year. The average number of days with snow cover is 66 , while the average thickness of snow cover is $25 \mathrm{~cm}$. Frequent weather changes and the occurrence of rainfall are accompanied by atmospheric fronts, which move over the area of Sosnowiec $40.5 \%$ of days a year. Among winds occurring in Sosnowiec, the wind from the west is dominant, next from the south, the north-west and south-west. The average wind speed in Sosnowiec is estimated at around $3.1 \mathrm{~m} \cdot \mathrm{s}^{-1}[9]$.

\section{Aim}

The aim of this research was to compare the concentration of aeroplankton (pollen grains and fungal spores) at three different heights and to check the daily count of pollination and sporulation at specific hours. An important aspect was also to investigate the influence of weather conditions on the differences in individual concentrations.

\section{Material and method}

Concentrations of pollen grains and fungal spores were analyzed on the basis of data obtained in Sosnowiec on July $3^{\text {rd }}-5^{\text {th }}, 2018$. Aerobiological measurements were made by applying the volumetric method with the use of three special Burkard devices. The apparatuses were located at an altitude of about $83 \mathrm{~m}, 15 \mathrm{~m}$ and near ground level on the premises of the Faculty of Earth Sciences at Silesian University in Sosnowiec. The geographical coordinates of the measuring point are: $50^{\circ} 17^{\prime} 50^{\prime \prime} \mathrm{N}$ and $19^{\circ} 08^{\prime} 20^{\prime \prime}$ E. Near the volumetric apparatuses, a meteorological station of the Department of Climatology (height $263 \mathrm{~m}$, ASL) is situated, from which the weather data was used. The height samplers placed at an altitude of $83 \mathrm{~m}$ and near the ground level were portable (personal volumetric air samplers), in which glass slides with an adhesive substance were exchanged every hour. The apparatus at $15 \mathrm{~m}$ was a classic device that takes samples continuously. Measurements were conducted from 8 am to $8 \mathrm{pm}$. Sampling during night hours was impossible due to limitations of personal devices that cannot operate in high humidity conditions. For this reason, the days selected for the measurements were those in which high-pressure weather without rainfall prevailed. On July $3^{\text {rd }}, 2018$ southern Poland came under the influence of a weak high-pressure system extending from Germany and the Czech Republic through Hungary and Romania towards the Black Sea. Old polar maritime air masses flowed in from the west and north west. In Sosnowiec, after a clear night, the sky was moderately overcast with cumulus clouds. On the night of July $4^{\text {th }}$, the advection from the north-west and the east weakened. In the hazy area of elevated pressure, the old polar maritime air was still present. The day was clear with sunshine for 15.2 hours. On July $5^{\text {th }}$, atmospheric pressure dropped below $1010 \mathrm{hPa}$ and southern Poland found itself in a weak low-pressure air mass near the stationary front surging over the Czech Republic. This front was located near Sosnowiec at around $8 \mathrm{pm}$, bringing a warm polar maritime air mass. The day was sunny, as only in the evening there was an increase in cloud cover. The average temperature on the analyzed days in the meteorological station was $25.3^{\circ} \mathrm{C}$, the relative humidity was $31.3 \%$, and the western wind with the speed of $2 \mathrm{~m} \cdot \mathrm{s}^{-1}$ was predominant. July $4^{\text {th }}$ and $5^{\text {th }}$ were hot days, the maximum temperature was $27.8^{\circ} \mathrm{C}$ and $31^{\circ} \mathrm{C}$ respectively. At an altitude of $83 \mathrm{~m}$, the average air temperature was lower $\left(23.5^{\circ} \mathrm{C}\right)$ and the wind speed was higher. At the above-mentioned altitude, sunshine hours were also measured, which on the examined days averaged 10.6 hours. On July $4^{\text {th }}$, the highest total radiation of $27.4 \mathrm{MJ} \cdot \mathrm{m}^{-2}$ was recorded. Both average daily and hourly values of meteorological elements such as: average air temperature, length of sunshine, solar radiation, relative humidity, average wind speed, maximum gust and wind direction were used in the research.

The analysis of pollen grains and fungal spores was carried out by light microscope after staining with basic fuchsin. The palynomorphs were counted and designated in 13 vertical ranges, each corresponding to an hourly range from 8 am to 8 pm respectively. 45 taxa including 29 taxa of fungal spores and 16 taxa of pollen 
grains were determined (tab. 1). The "unknown" category includes non-designated fungal spores. In total, 66,721 palynomorphs were designated.

In order to determine the effect of meteorological conditions on the height of pollen grains and fungal spores, a correlation analysis was performed. Due to the fact that the data distribution was not normal (Shapiro-Wilk test), the non-parametric Spearman's rank correlation coefficient was used. The statistical risk of error was estimated at the significance level: $a=0.05$, 0.01 and 0.001 using the Statistica version 9 program.

\section{Results}

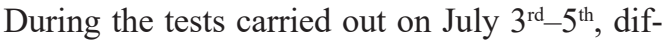
ferences were observed in the values of pollen and spore concentrations at various heights (fig. 2, 3) and at different times (fig. 4). By far the largest proportion of designated palynomorphs were fungal spores, the most numerous of which was genus Cladosporium, followed by Alternaria, Epicoccum and Botrytis (tab. 2). The dominant taxon among plants was nettle (Urtica), whose pollen in the analyzed days reached a total of 5060 grains per $\mathrm{m}^{3}$ (tab. 2). Considering the taxa of plants and fungi together, the highest number of palynomorphs were collected at the lowest measuring point, that is at the ground level (fig. 2). At this point, much higher concentrations of fungal spores were observed, such as: Alternaria, Aspergillus/Penicillium, Arthrinium, Botrytis, Chaetomium, Cladosporium, Epicoccum, Pithomyces and Stemphylium, and higher concentrations of pollen grains: Artemisia, Brassicaceae, Labiateae and Plantago (tab. 2).

When analyzing pollen grains and fungal spores, it was found that the highest number of pollen grains were caught at a height of $15 \mathrm{~m}$ (fig. 3). These were mainly pollen grains belonging to the Poaceae family and to the genus Urtica (tab. 2). Pollination in individual hours is illustrated in the graphs in figures 5-7. The largest fluctuations in the surveyed days occurred at $15 \mathrm{~m}$ among plant taxa (fig. 6). The graphs show one distinct peak between 9-10 and then a dramatic fall in the number of pollen grains around noon. A similar situation was observed in the number of fungal spores at the ground level. On all days at 10 am there is a peak with a high concentration of fungal spores followed by a sudden drop in concentration (fig. 5).

Statistical analysis revealed that the level of concentration of fungal spores and pollen grains was most influenced by wind speed, maximum gust of wind and solar radiation. A high, statistically significant correlation was found between the palynomorph concen- tration, the wind speed and the maximum gust of wind. Only for the measuring point at $83 \mathrm{~m}$ was the correlation negative (tab. 3), while for the other two measuring points it was positive (tab. 4,5 ). It can be stated that the high wind speed at high altitude causes the reduction of the palynomorph concentration. At lower altitudes (15 $\mathrm{m}$ and at the ground), on the contrary, high concentrations of pollen and spores appeared when the wind speed and maximum gust of wind were high.

The correlation between palynomorph concentration and solar radiation at all measuring points was positive (tab. 3-5). A statistically crucial negative correlation with wind direction was also found (tab. 3-5). Higher concentrations of palynomorph at all heights were favored by a south-west wind, while the palynomorph number was smaller with a western wind. Correlations with average air temperature and relative humidity were weaker and in some cases statistically insignificant (tab. 3-5).

\section{Discussion}

Pollen grains are one of the most important groups of biological particles in the atmosphere that trigger allergic processes. Knowledge of aeroplankton variability may be useful in the treatment and prevention of pollen and spore allergies. Multiple fluctuations in the number of palynomorphs during the day are related to diurnal opening of anthers, which is modified by various factors [10-12]. The flowering, pollen and fungal spore production of particular species are influenced by genetic, phenological, ecological, meteorological and climatic factors. Estimating the variability of the number of pollen and spores makes it possible to assess the risk posed by allergens in a given area. As early as 1883, Miquel [13] proved that microbes floating in the air indicate certain circadian rhythms. Fungi release spores only under specific conditions of temperature, humidity and light [14]. Some plants produce pollen in the morning hours, others in the afternoon [10, 15]. With changing weather conditions (rain, wind direction, turbulence, sunshine, etc.) there is practically no regular pattern or rhythm according to which pollen grains and fungal spores would appear in the air [16-18]. Studies on the hourly distribution of pollen grains and fungal spores in many countries showed how diverse the daily pollen rhythms are [10, 12, 15, 19-26].

In Sosnowiec, the largest fluctuations in the circadian course of pollination occurred at the lowest measuring point, that is at the ground (fig. 4). One clear peak can be noticed with a high concentration at 
Figure 1. The geographic location of Sosnowiec in Central Europe (www.vecteezy.com/map-vector).

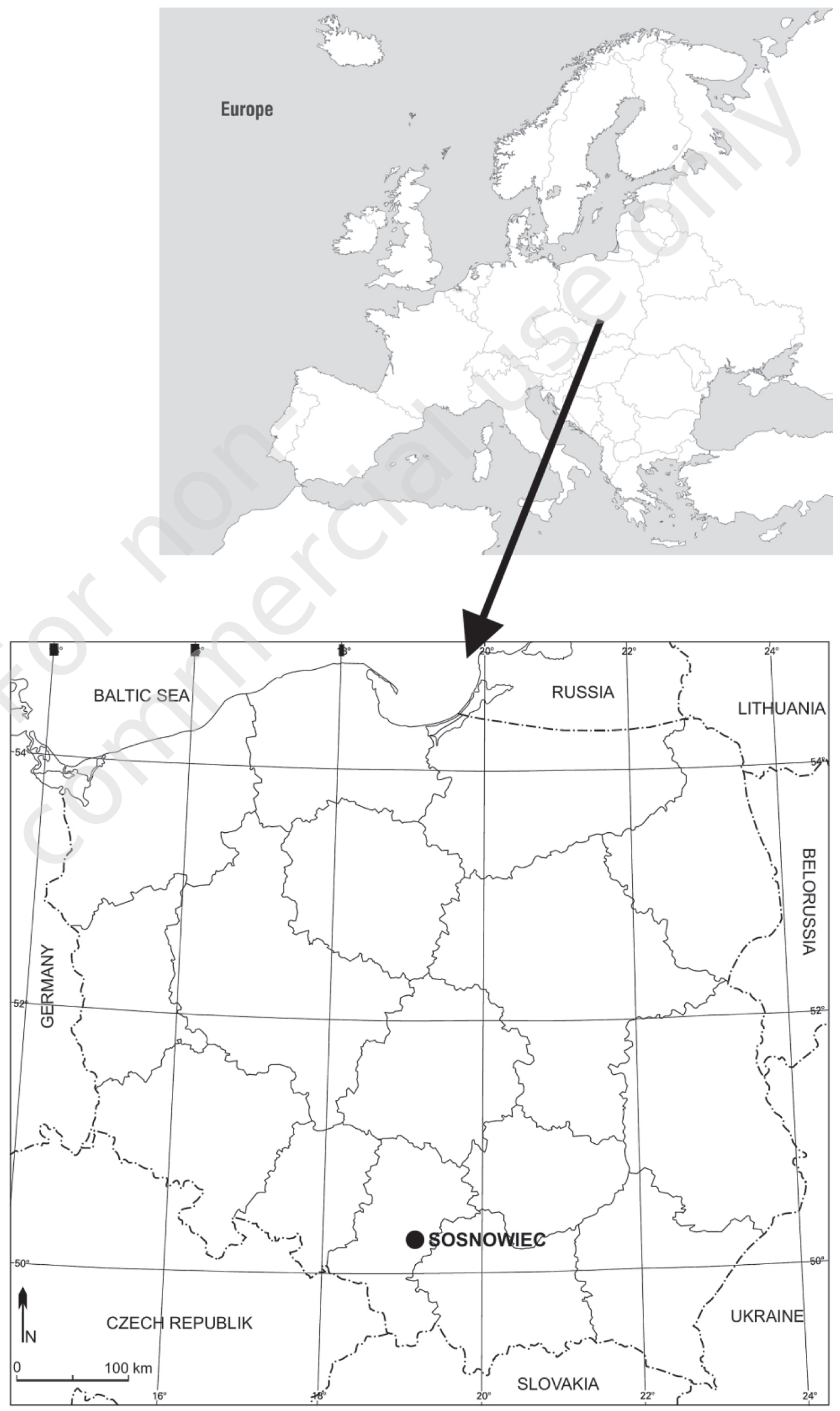
https://www.journalsmededu.pl/index.php/alergoprofil: 26.04.2023; 14:30,39 


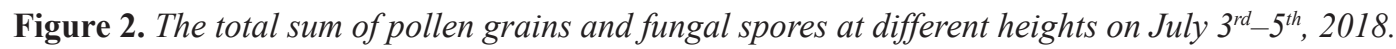

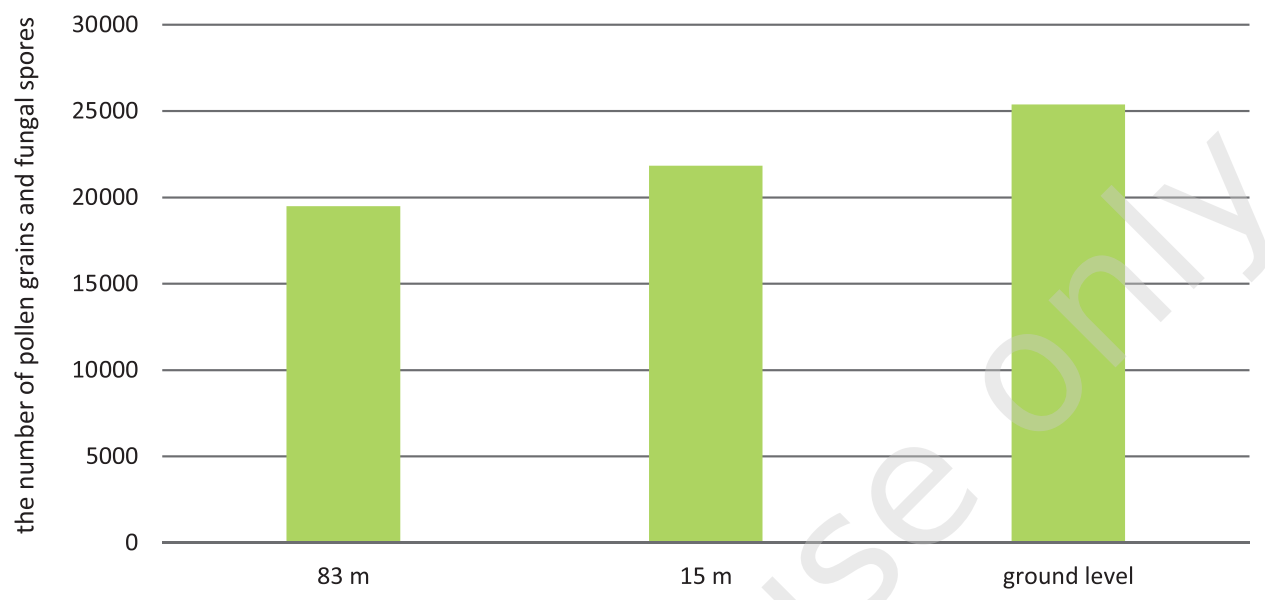

Figure 3. The differences in the concentration of pollen grains and fungal spores at different heights on July $3^{\text {rd }}-5^{\text {th }}$, 2018.

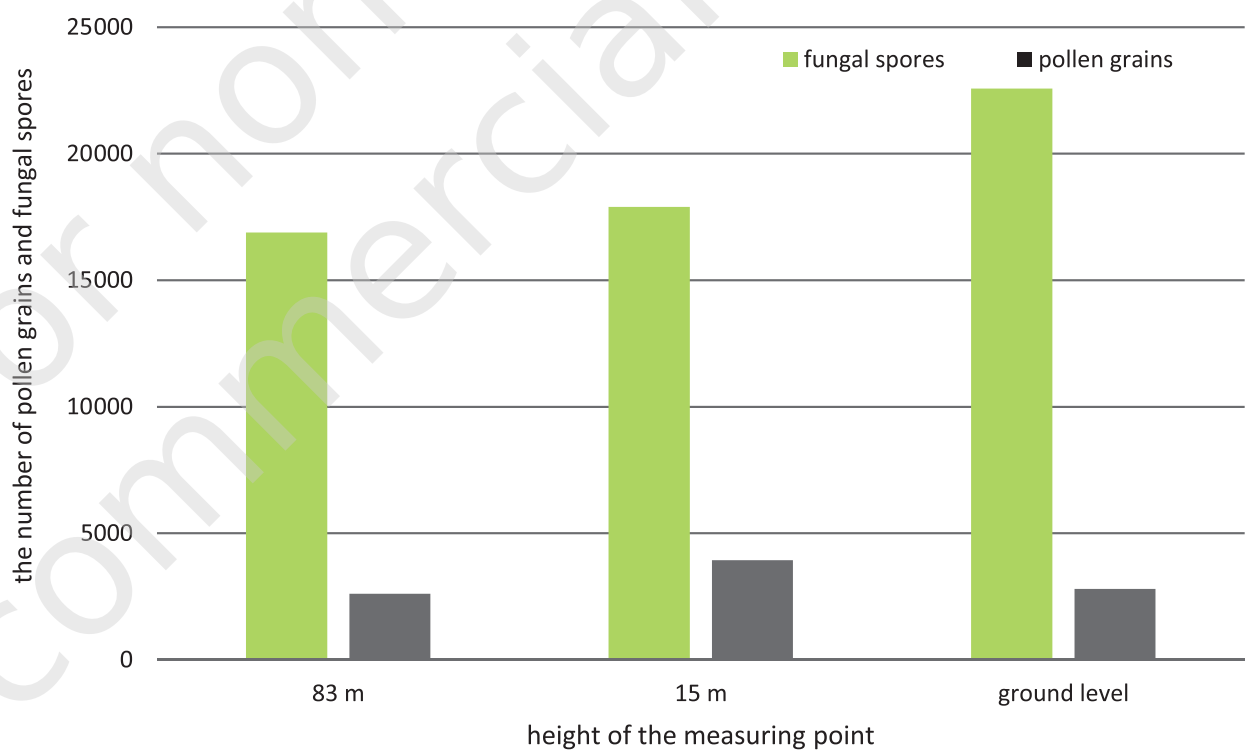

Figure 4. Hourly pollen and spore course at various heights (hours in summer time $8=06$ UTC).

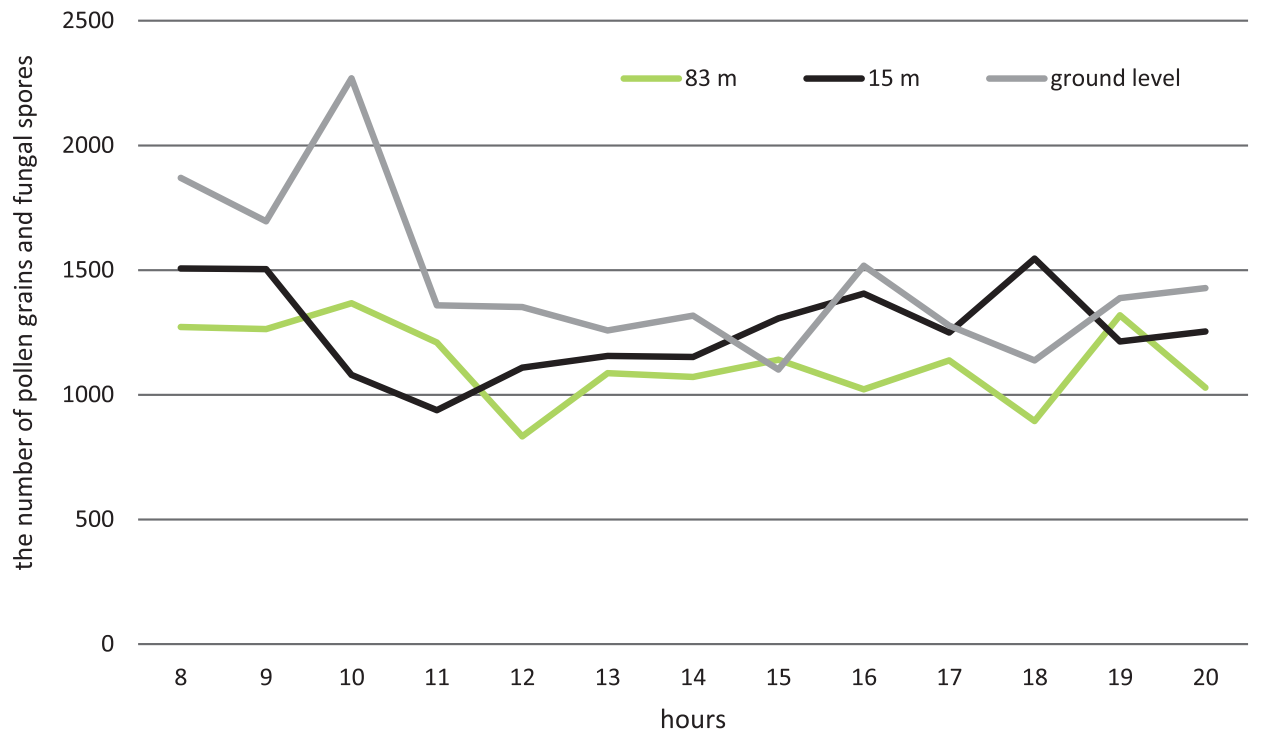


Figure 5. The comparison of concentration of pollen grains and fungal spores in one-hour intervals at a height of $83 \mathrm{~m}$ (hours in summer time $8=06$ UTC).
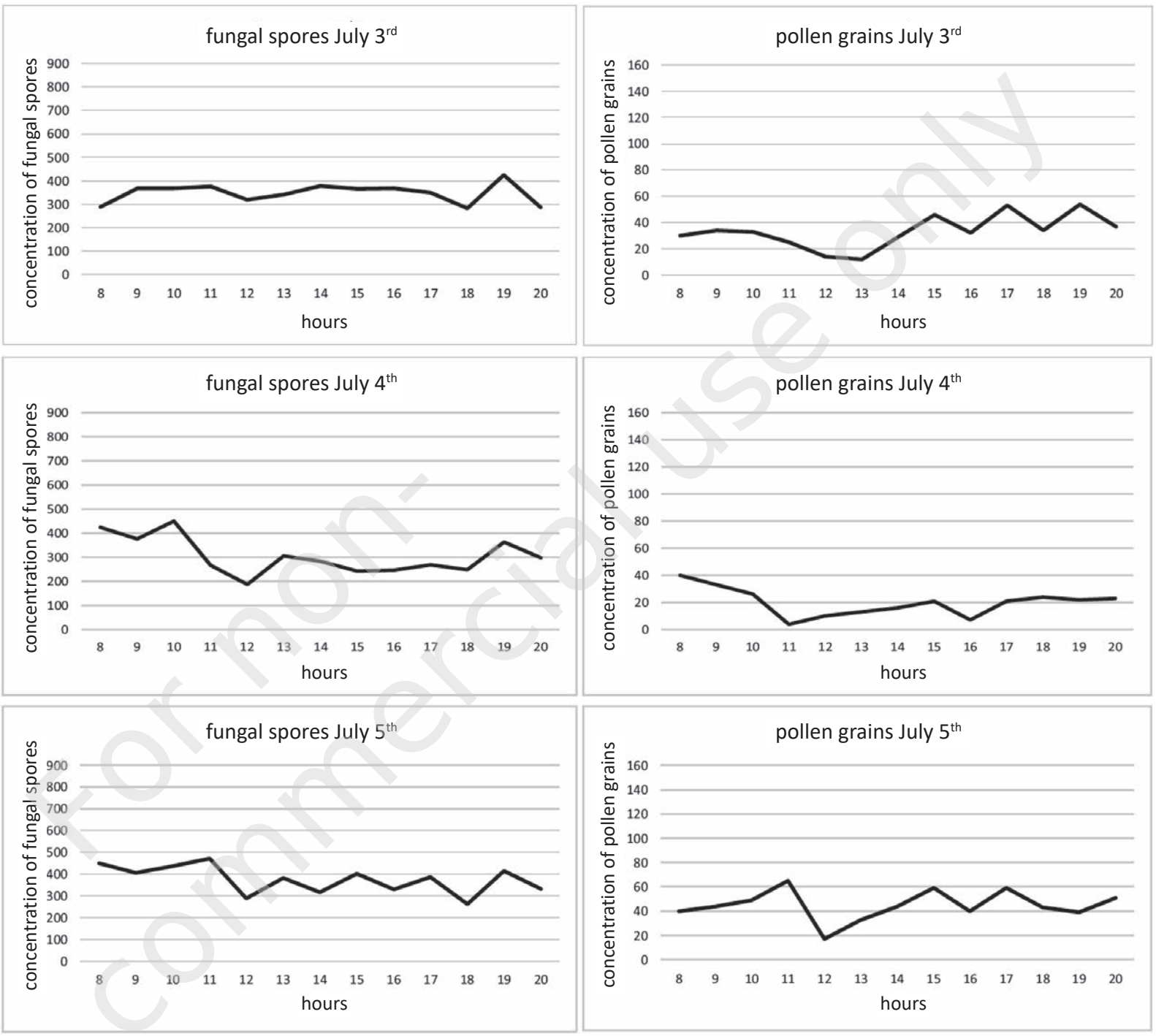

10 o'clock, with a radical decrease in the number of grains and spores after 10. By treating pollen grains and fungal spores separately, the most diverse diurnal course occurred at the height of $15 \mathrm{~m}$ among plant taxa (fig. 7). The graphs show one distinct peak between 9-10 and then a decrease in the number of pollen grains around noon. To some extent, this may be connected to the wind speed strength and solar radiation values, which is confirmed by high correlation coefficients for these weather elements (tab. 4). Grass pollen analyses carried out by Dutch [17] and Spanish researchers [22] indicate, however, that the relationship between the concentration of pollen grains and individual meteorological elements may be dependent not only on the time of day, but also on the season of the year. A similar pollination course of plants with one distinct peak in the afternoon hours was found in Finland [27] and in Spain $[22,28]$; while in the Netherlands [17], Wales [29] and
Denmark [24] maximum concentrations were observed in the afternoon. One clear peak around 10 o'clock was also observed for the sporulation course at the measurement point near the ground (fig. 6). At this time, the concentrations of Alternaria, Aspergillus/Penicillium, Cladosporium, Epicoccum and Pithomyces spores were higher than in the remaining hours. At 10 o'clock at the indicated measurement point, a sudden increase in the value of solar radiation and wind speed was also noted. The correlation coefficients for these weather elements were positive (tab. 5).

Statistical analysis showed that the higher concentration of fungal spores and pollen grains was most influenced by the wind speed, maximum gust of wind and solar radiation. A high, statistically significant correlation was found between the palynomorph concentration, the wind speed and the maximum gust of wind. Only for the measuring point at $83 \mathrm{~m}$ was the corre- 
Figure 6. The comparison of concentration of pollen grains and fungal spores in one-hour intervals at ground level (hours in summer time $8=06$ UTC).
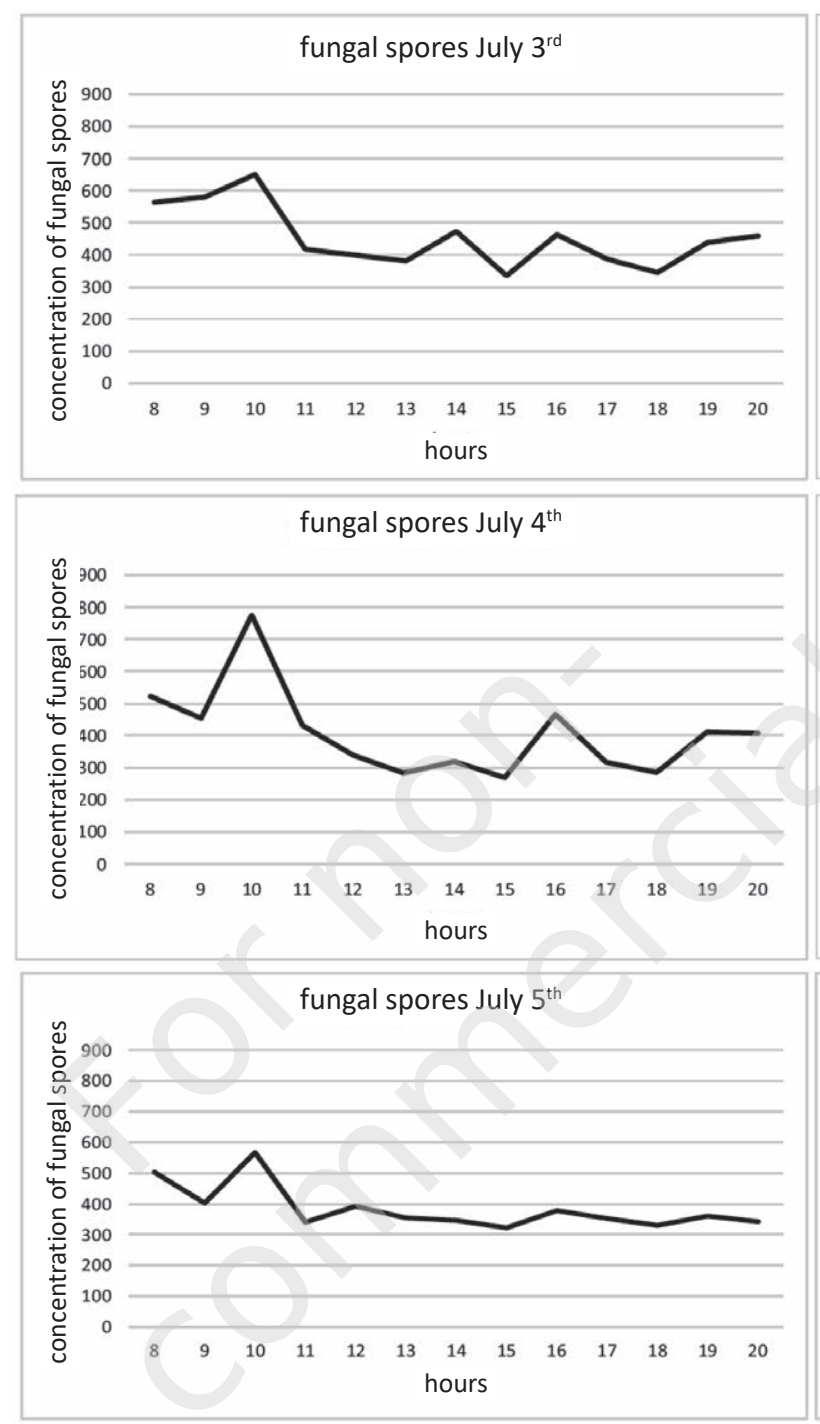

lation negative (tab. 3), while for the other two measuring points it was positive (tab. 4, 5). The correlation between palynomorph concentration and solar radiation at all measuring points was positive (tab. 3-5). Many researchers emphasize the role of wind and solar radiation in affecting the concentration of pollen grains and fungal spores in the air [25, 30-33].

In the studies carried out in Sosnowiec, a statistically significant negative correlation with the wind direction was also found (tab. 3-5). Higher concentrations of palynomorphs at all heights were favored by the wind from the south-west. The palynomorph number was smaller with wind from the western direction. Correlations with average air temperature were positive at all measuring points (tab. 3-5), which was also found in studies conducted, among others, in New Zealand [34], Portugal [35], Romania [36] and China [37]. Correlation coefficients between relative humidi-
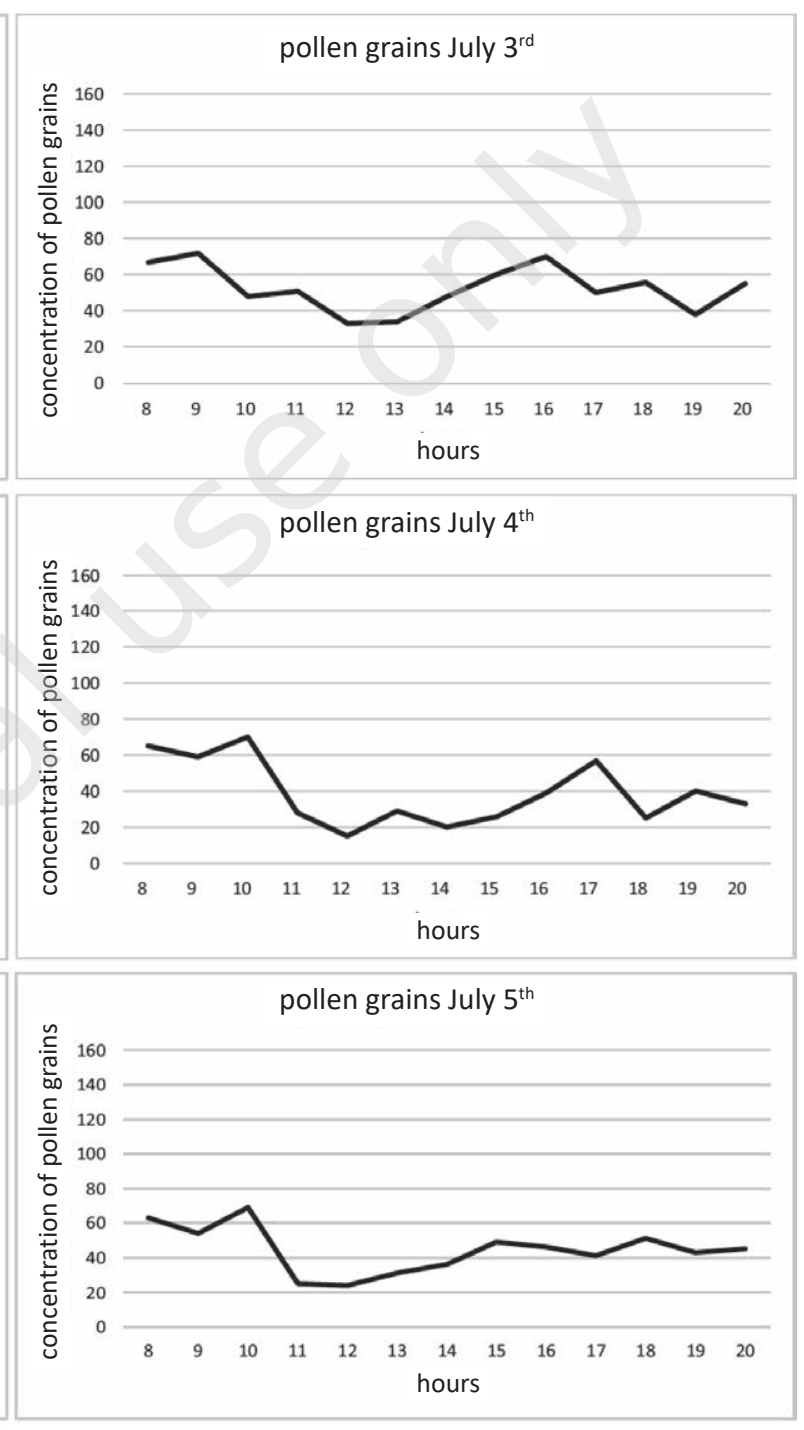

ty and pollen grain concentration were negative, while correlation coefficients between the indicated weather element and the concentration of fungal spores were positive (tab. 3-5). A negative correlation with relative humidity was also found in studies conducted in Pakistan [25] and in Slovakia [33].

The concentration of pollen grains and fungal spores also depends on the sampler height, which has also been often emphasized by other researchers $[6,7$, 38-40]. In general, particle concentrations tend to decrease with altitude [1-4, 41], and this relationship was applicable for Sosnowiec. The spore particles of some types of fungi (Aspergillus-type, Cladosporium) may be more numerous at measuring points located higher, due to the fact that they are small and light, thus easily transported by the wind. According to some researchers [42], their number even increases with altitude. In Sosnowiec, however, no such relationship was found. 
Figure 7. The comparison of concentration of pollen grains and fungal spores in one-hour intervals at a height of $15 \mathrm{~m}$ (hours in summer time $8=06$ UTC).
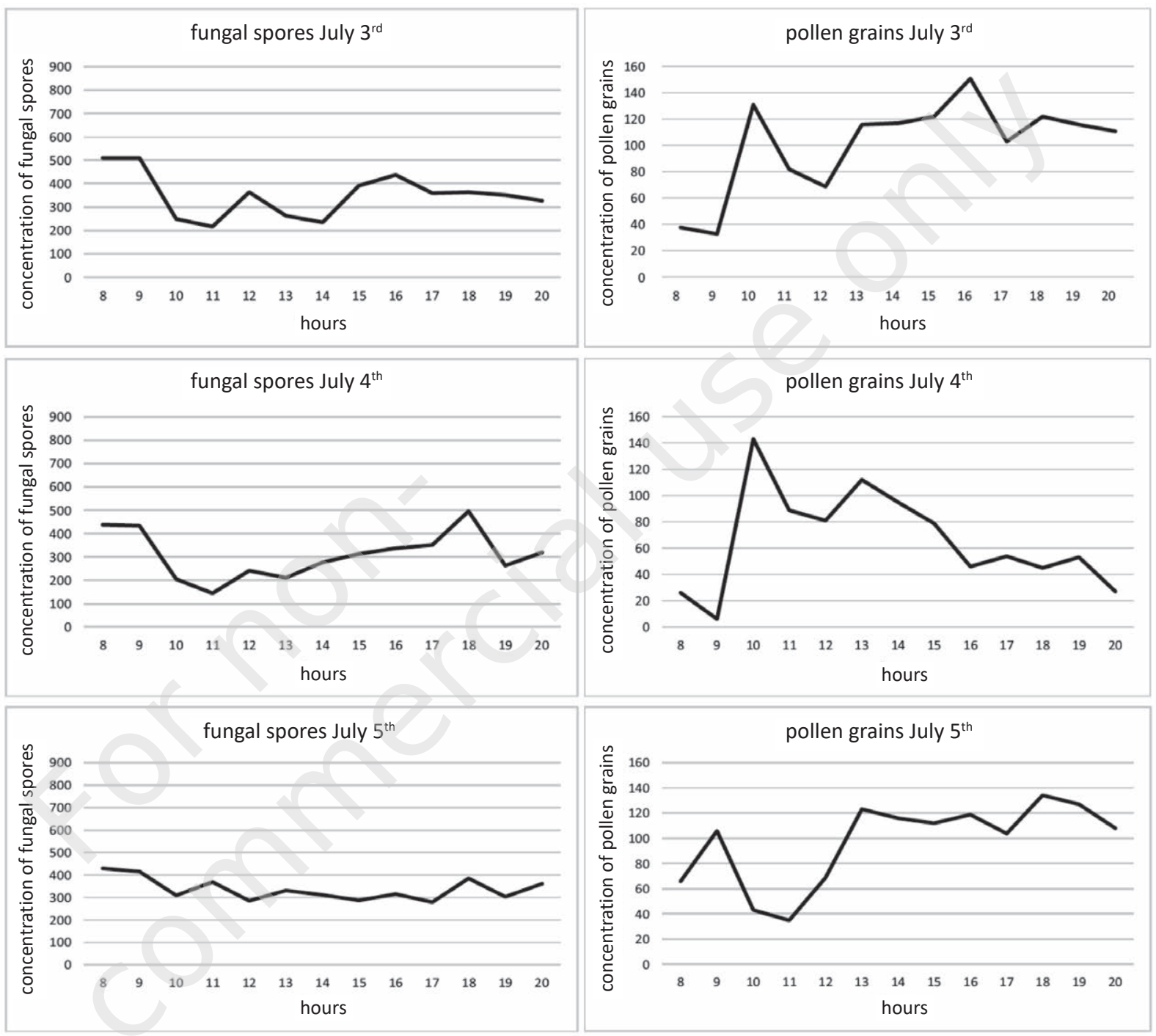

Considering all the palynomorphs together: the highest concentrations were recorded at the ground level, and the lowest at the height of $83 \mathrm{~m}$ (fig. 2). The largest part of designated palynomorphs were fungal spores, the most numerous being genus Cladosporium, followed by Alternaria, Epicoccum and Botrytis (tab. 2). Cladosporium spores have also been the most representative fungal spores in research in other countries $[25,33,39]$. Some researchers suggest that high concentrations of certain fungal spores and pollen grains by the ground may be the result of a combination of several factors [27, 42, 43]. These factors are: the source proximity from which the aeroplankton originates, i.e. soil and vegetation, aerodynamic characteristics of the aeroplankton: shape and size of grains and spores, the effect of meteorological conditions on pollen release, dispersion and deposit of the aeroplankton and vertical temperature gradient. The mentioned factors may explain lower concentrations of fungal spores and pollen grains at the roof level than at ground level. Many spores come from fungi that live on rotting parts of plants or are parasites of living plants. The concentration of spores should be higher, the closer they are to the source, that is the ground; and this is actually the case. The same applies to plant pollen, which reaches higher concentrations at the mother plant, i.e. at the measuring point closest to the ground.

In Sosnowiec, however, both nettle and grass pollen, which occurred in the analyzed days most abundantly, reached the highest concentrations not at the ground, but at the $15 \mathrm{~m}$ point (tab. 2). Nettle and grass pollen usually reach very high concentrations in the atmosphere, which is also confirmed by other researchers [44, 45]. Nettle pollen grains belong to a small and light group of particles that can easily be carried by air currents, as shown by analyses carried 
Table 1. The number of pollen grains and fungal spores marked at different heights on July $3^{\text {rd }}-5^{\text {th }}$.

\begin{tabular}{|c|c|c|c|c|c|c|c|c|c|}
\hline & \multicolumn{3}{|c|}{ July 3rd } & \multicolumn{3}{|c|}{ July $4^{\text {th }}$} & \multicolumn{3}{|c|}{ July $5^{\text {th }}$} \\
\hline & $83 \mathrm{~m}$ & $15 \mathrm{~m}$ & ground level & $83 \mathrm{~m}$ & $15 \mathrm{~m}$ & ground level & $83 \mathrm{~m}$ & $15 \mathrm{~m}$ & ground level \\
\hline Fungal spores & 5631 & 6516 & 8033 & 5065 & 5665 & 7300 & 6186 & 5723 & 7247 \\
\hline Pollen grains & 946 & 1249 & 976 & 776 & 1094 & 925 & 895 & 1598 & 896 \\
\hline Sum & 6577 & 7765 & 9009 & 5841 & 6759 & 8225 & 7081 & 7321 & 8143 \\
\hline
\end{tabular}

Table 2. The number of all taxa marked at different heights.

\begin{tabular}{|l|l|l|l|l|}
\hline \multicolumn{1}{|c|}{ Taxon } & $83 \mathrm{~m}$ & $15 \mathrm{~m}$ & Ground level & Sum \\
\hline Alternaria & 944 & 2463 & 2723 & $\mathbf{6 1 3 0}$ \\
\hline Ambrosia & 0 & 3 & 7 & $\mathbf{9}$ \\
\hline Artemisia & 28 & 24 & 245 & $\mathbf{2 9 7}$ \\
\hline Aspergillus/Penicillium & 116 & 136 & 250 & $\mathbf{5 0 2}$ \\
\hline Arthrinium & 345 & 385 & 445 & $\mathbf{1 1 7 6}$ \\
\hline Asteraceae & 9 & 5 & 5 & $\mathbf{2 0}$ \\
\hline Aureobasidium & 39 & 41 & 32 & $\mathbf{1 1 2}$ \\
\hline Botrytis & 156 & 219 & 558 & $\mathbf{9 3 3}$ \\
\hline Brassicaceae & 4 & 4 & 17 & $\mathbf{2 5}$ \\
\hline Cercospora & 16 & 36 & 25 & $\mathbf{7 7}$ \\
\hline Chaetomium & 37 & 53 & 240 & $\mathbf{3 3 1}$ \\
\hline Chenopodiaceae & 28 & 64 & 31 & $\mathbf{1 2 3}$ \\
\hline Cladosporium & 14428 & 12289 & 16302 & $\mathbf{4 3 0 1 9}$ \\
\hline Didymella & 47 & 35 & 49 & $\mathbf{1 3 1}$ \\
\hline Dreschlera & 63 & 89 & 84 & $\mathbf{2 3 6}$ \\
\hline Epicoccum & 329 & 267 & 657 & $\mathbf{1 2 5 3}$ \\
\hline Fabaceae & 5 & 3 & 25 & $\mathbf{3 3}$ \\
\hline Fusicladium & 31 & 24 & 47 & $\mathbf{1 0 1}$ \\
\hline Ganoderma & 345 & 340 & 163 & $\mathbf{8 4 8}$ \\
\hline Gymnosporangium & 52 & 56 & 84 & $\mathbf{1 9 2}$ \\
\hline Helminthosporium & 25 & 29 & 31 & $\mathbf{8 5}$ \\
\hline Mucor & 76 & 136 & 107 & $\mathbf{3 1 9}$ \\
\hline Labiatae & 7 & 45 & $\mathbf{5 5}$ \\
\hline
\end{tabular}

\begin{tabular}{|l|l|l|l|l|}
\hline Leptosphaeria & 52 & 73 & 39 & $\mathbf{1 6 4}$ \\
\hline Periconia & 57 & 39 & 45 & $\mathbf{1 4 1}$ \\
\hline Peronospora & 48 & 16 & 57 & $\mathbf{1 2 1}$ \\
\hline Picea & 1 & 5 & 7 & $\mathbf{1 3}$ \\
\hline Pinus & 23 & 43 & 29 & $\mathbf{9 5}$ \\
\hline Pithomyces & 49 & 45 & 145 & $\mathbf{2 4 0}$ \\
\hline Plantago & 93 & 165 & 211 & $\mathbf{4 6 9}$ \\
\hline Poaceae & 451 & 993 & 691 & $\mathbf{2 1 3 5}$ \\
\hline Pteridophyta & 15 & 47 & 29 & $\mathbf{9 1}$ \\
\hline Puccinia & 44 & 40 & 35 & $\mathbf{1 1 9}$ \\
\hline Rhizopus & 136 & 111 & 99 & $\mathbf{3 4 5}$ \\
\hline Rosaceae & 1 & 4 & 4 & $\mathbf{9}$ \\
\hline Rumex & 155 & 127 & 143 & $\mathbf{4 2 4}$ \\
\hline Stemphylium & 72 & 121 & 239 & $\mathbf{4 3 2}$ \\
\hline Thecaphora & 4 & 8 & 4 & $\mathbf{1 6}$ \\
\hline Tilia & 4 & 20 & 11 & $\mathbf{3 5}$ \\
\hline Tilletia & 17 & 15 & 27 & $\mathbf{5 9}$ \\
\hline Torula & 69 & 61 & 71 & $\mathbf{2 0 1}$ \\
\hline Tuburcinia & 24 & 16 & 21 & $\mathbf{6 1}$ \\
\hline Uromyces & 63 & 41 & 35 & $\mathbf{1 3 9}$ \\
\hline Urtica & 21845 & $\mathbf{2 5 3 7 7}$ & $\mathbf{6 6 7 2 1}$ \\
\hline Ustilago & 3059 & 1120 & $\mathbf{5 0 6 0}$ \\
\hline Unknown & 33 & 45 & $\mathbf{1 2 1}$ \\
\hline Sum & 55 & 99 & $\mathbf{2 2 3}$ \\
\hline
\end{tabular}

out by Spanish researchers [46]. Among the designated pollen grains, nettle was the only one that was most represented at $15 \mathrm{~m}$, while the pollen of other plants reached the highest concentration at $1.5 \mathrm{~m}$. There is no clear answer why the heavier and larger pollen belonging to the Poaceae family was found in greater amounts at a height of $15 \mathrm{~m}$, but this means that the risk of grass pollen allergens may also be probable at higher altitudes, far from the source of pollen.

The values of pollen grain concentration at other measuring points, i.e. at $83 \mathrm{~m}$ and at the ground were comparable (fig. 3).

Changes in aeroplankton concentration along with the change in altitude seem to be important, espe- 
Table 3. The correlation coefficients between the average values of the weather conditions and the pollen and spores concentrations from 8 am to 8 pm on July $3^{\text {rd }}-5^{\text {th }}$ at a height of $83 \mathrm{~m}$.

\begin{tabular}{|c|c|c|c|c|c|c|}
\hline \multirow{3}{*}{ Meteorological conditions } & \multicolumn{6}{|c|}{$83 \mathrm{~m}$} \\
\hline & \multicolumn{2}{|c|}{ July $3^{\text {rd }}$} & \multicolumn{2}{|c|}{ July $4^{\text {th }}$} & \multicolumn{2}{|c|}{ July $5^{\text {th }}$} \\
\hline & pollen & spores & pollen & spores & pollen & spores \\
\hline Average temperature & 0.33 & $0.68^{*}$ & 0.53 & $0.63^{*}$ & 0.07 & $0.61^{*}$ \\
\hline Relative humidity & -0.45 & $0.65^{*}$ & $-0.62^{*}$ & $0.64^{*}$ & -0.48 & $0.63^{*}$ \\
\hline Wind direction & -0.14 & 0.24 & -0.36 & -0.23 & 0.01 & -0.46 \\
\hline Wind speed & $-0.72^{\star \star}$ & $-0.59^{*}$ & $-0.81^{\star \star \star}$ & $-0.63^{*}$ & $-0.65^{\star}$ & -0.51 \\
\hline Maximum gust of wind & $-0.78^{\star *}$ & $-0.66^{*}$ & $-0.83^{* * *}$ & $-0.60^{*}$ & $-0.69^{*}$ & $-0.59^{*}$ \\
\hline Sunshine duration & -0.48 & 0.40 & -0.47 & -0.23 & -0.19 & 0.18 \\
\hline Solar radiation & 0.32 & $0.62^{*}$ & 0.06 & $0.65^{\star}$ & 0.25 & $0.70^{\star *}$ \\
\hline
\end{tabular}

${ }^{*} p<0.05 ;{ }^{* *} p<0.01 ;{ }^{* * *} p<0.001$

Table 4. The correlation coefficients between the average values of the weather conditions and the pollen and spores concentrations from 8 am to $8 \mathrm{pm}$ on July $3^{\text {rd }}-5^{\text {th }}$ at a height of $15 \mathrm{~m}$.

\begin{tabular}{|c|c|c|c|c|c|c|}
\hline \multirow{3}{*}{ Meteorological conditions } & \multicolumn{6}{|c|}{$15 \mathrm{~m}$} \\
\hline & \multicolumn{2}{|c|}{ July $3^{\text {rd }}$} & \multicolumn{2}{|c|}{ July $4^{\text {th }}$} & \multicolumn{2}{|c|}{ July $5^{\text {th }}$} \\
\hline & pollen & spores & pollen & spores & pollen & spores \\
\hline Average temperature & $0.59^{*}$ & 0.45 & $0.60^{*}$ & 0.33 & 0.48 & $0.58^{\star}$ \\
\hline Relative humidity & $-0.65^{\star}$ & $0.64^{*}$ & 0.45 & $0.61^{*}$ & -0.40 & $0.59^{*}$ \\
\hline Wind direction & $-0.60^{\star}$ & $-0.59^{\star}$ & $-0.70^{\star *}$ & $-0.69^{* *}$ & $-0.63^{*}$ & $-0.70^{\star * *}$ \\
\hline Wind speed & $0.67^{*}$ & $0.69^{* *}$ & $0.78^{* *}$ & $0.59^{*}$ & $0.78^{* *}$ & $0.73^{* *}$ \\
\hline Maximum gust of wind & $0.60^{*}$ & $0.59^{*}$ & $0.71^{* *}$ & $0.67^{*}$ & $0.83^{\star \star \star}$ & $0.81^{* * *}$ \\
\hline Solar radiation & $0.82^{* * *}$ & $0.72^{\star *}$ & $0.66^{*}$ & $0.78^{\star *}$ & $0.71^{\star *}$ & $0.86^{\star * *}$ \\
\hline
\end{tabular}

${ }^{*} p<0.05 ;{ }^{* *} p<0.01 ; * * * p<0.001$

Table 5. The correlation coefficients between the average values of the weather conditions and the pollen and spores concentrations from 8 am to 8 pm on July $3^{\text {rd }}-5^{\text {th }}$ at ground level.

\begin{tabular}{|c|c|c|c|c|c|c|}
\hline \multirow{3}{*}{ Meteorological conditions } & \multicolumn{6}{|c|}{ Ground level } \\
\hline & \multicolumn{2}{|c|}{ July $3^{\text {rd }}$} & \multicolumn{2}{|c|}{ July $4^{\text {th }}$} & \multicolumn{2}{|c|}{ July $5^{\text {th }}$} \\
\hline & pollen & spores & pollen & spores & pollen & spores \\
\hline Average temperature & $0.62^{*}$ & $0.59^{*}$ & $0.57^{\star}$ & 0.49 & $0.56^{\star}$ & $0.69 * *$ \\
\hline Relative humidity & -0.55 & $0.59^{*}$ & $-0.62^{*}$ & $0.60^{*}$ & $-0.58^{\star}$ & $0.62^{*}$ \\
\hline Wind direction & $-0.56^{*}$ & $-0.62^{*}$ & $-0.59^{*}$ & $0.71^{* *}$ & $-0.67^{\star}$ & $-0.70^{\star * *}$ \\
\hline Wind speed & $0.76^{\star *}$ & $0.68^{\star}$ & $0.80^{\star \star \star *}$ & $0.82^{* \star \star}$ & $0.72^{* \star}$ & $0.69^{* *}$ \\
\hline Maximum gust of wind & $0.66^{*}$ & 0.49 & $0.69^{* *}$ & $0.60^{*}$ & $0.70^{\star *}$ & $0.67^{*}$ \\
\hline Solar radiation & $0.78^{* *}$ & $0.59^{*}$ & $0.64^{*}$ & $0.68^{*}$ & $0.78^{* *}$ & $0.65^{*}$ \\
\hline
\end{tabular}

${ }^{*} \mathrm{p}<0.05 ;{ }^{* *} \mathrm{p}<0.01 ;{ }^{* * *} \mathrm{p}<0.001$ 
cially in relation to hay fever. Threats that may affect an average allergic person can vary significantly depending on whether one is at street level, or whether one lives or works in a high-rise block. Therefore, before starting aerobiological research in urban areas, it should be taken into account at what level the samples should be collected and for what purpose the results will be used. Samplers on tall buildings will give a general picture of pollen spectra over an extensive area, but have no relation to aeroplankton concentrations experienced by the population at ground level. On the other hand, samplers at lower levels will give a better picture of the aeroplankton concentration to which the potential allergic patient is exposed. It seems that the higher, the "safer".

\section{Conclusions}

In Sosnowiec, the greatest fluctuations in the daily pollen count were at the measuring point located at the lowest level, i.e. at the ground. Around 10 o'clock, the spore concentrations of Alternaria, Aspergillus/Penicillium, Cladosporium, Epicoccum and Pithomyces were higher than in the remaining hours.

The largest part of the marked palynomorphs were fungal spores, the most numerous of which was the genus Cladosporium, followed by Alternaria, Epicoccum and Botrytis.

Considering all palynomorphs together, the highest concentrations were recorded at the ground, the lowest at the height of $83 \mathrm{~m}$. Only nettle and grass pollen reached the highest concentrations at the measuring point located at $15 \mathrm{~m}$.

Statistical analysis showed that the highest concentrations of fungal spores and pollen grains were influenced by wind speed, maximum gust of wind and solar radiation. The direction of the wind was also significant, as the palynomorphs at all heights were favored by wind from the south-west.

The correlation coefficients between aeroplankton concentration and average air temperature were positive at all measuring points.

Correlation coefficients between relative humidity and pollen grain concentration were negative, while they were positive in the case of fungal spores.

\section{References}

1. Gregory PH. Distribution of airborne pollen and spores and their long distance transport. Pageoph. 1978; 116: 309-315.
2. Rantio-Lehtimäki A, Koivikko A, Kupias R et al. Significance of sampling height of airborne particles for aerobiological information. Allergy. 1991; 46(1): 68-76. https://doi.org/10.1111/j.1398-9995.1991.tb00545.x.

3. Galán C, Tormo $R$, Cuevas $J$ et al. Theoretical daily variations patterns of airborne pollen in the South -West of Spain. Grana. 1991; 30: 201-209. https://doi. org/10.1080/00173139109427800

4. Bergamini BM, Grillenzoni S, Andreoni AD et al. Alternaria spores at different heights from the ground. Allergy. 2004; 59: 746-752. https://doi.org/10.1111/j.1398-9995.2004.00423.x.

5. Mandrioli P, Negrini $M G$, Cesari $G$ et al. Evidence for long range transport of biological and anthropogenic aerosol particles in the atmosphere. Grana. 1984; 23: 43-53. https://doi. org/10.1080/00173138409428876.

6. Davies RR. Pollen and fungal spores in the city atmosphere. Acta Allergol. 1965; 20: 508.

7. Raynor GS, Ogden EC, Hayes JV. Variation in ragweed pollen concentration to a height of $108 \mathrm{~m}$. J Allergy Clin Immun. 1973; 51(4): 199-207. https://doi.org/10.1016/00916749(73)90139-5.

8. Jędrzejko K. Tereny zielone Sosnowca, charakterystyka florystyczno- ekologiczna. In: Wanatowicz M (ed). Rocznik Sosnowiecki 1993. Urząd Miejski w Sosnowcu, Sosnowiec 1993, 2: 116-139.

9. Niedźwiedź T, Małarzewski Ł. Klimat Sosnowca. In: Barciak A, Jankowski AT (ed). Sosnowiec. Obraz miasta i jego dzieje. Muzeum w Sosnowcu 2016, 1: 74-86.

10. Käpylä M. Diurnal variation of tree pollen in the air in Finland. Grana. 1984; 23: 167-176. https://doi. org/10.1080/00173138409427712

11. Kasprzyk I, Uruska A, Szczepanek $K$ et al. Regional differentiation in the dynamics of the pollen seasons of Alnus, Corylus and Fraxinus in Poland (Preliminary results). Aerobiologia. 2004; 20: 141-151. https://doi.org/10.1023/B:AERO.0000032951.25974.c9.

12. Nitiu DS. Intradiurnal fluctuation of pollen in La Plata, Argentina. Part I, herbaceous pollen types. Aerobiologia. 2004; 20(1): 69-74. https://doi.org/10.1023/B:AERO.0000022986.59858.28.

13. Miquel MP. Les organismes vivants de l'atmosphere. Gauthier -Villars. Paris 1883. https://doi.org/10.5962/bhl.title.1692.

14. Ingold CT. Fungal spores: their liberation and dispersal. Clarendon Press, Oxford 1971, 4: 302.

15. Käpylä M. Diurnal variation of non-arboreal pollen in the air in Finland. Grana. 1981; 20: 55-59. https://doi. org/10.1080/00173138109436737.

16. Spieksma FTM. Fluctuations in grass-pollen counts in relation to nightly inversion and air pollution potential of the atmosphere. Int J Biometeorol. 1983; 27: 107-116. https://doi. org/10.1007/BF02185740. 
17. Spieksma FTM, den Tonkelaar JF. Four hourly fluctuations in grass pollen concentrations in relation to wet versus dry weather, and to short versus overland advection. Int J Biometeorol. 1986; 30: 351-358. https://doi.org/10.1007/BF02189373.

18. Corden JM, Millington WM. The long term trends and seasonal variation of theaeroallergen Alternaria in Derby, UK. Aerobiologia. 2001; 17: 127-136.

19. Mäkinen Y, Ollikainen P. Diurnal and seasonal variations in the airspora composition in Turku, S. Finland. In: Nilsson S (ed). Scandinavian aerobiology. Bull Ecol Res Comm. 1973; 18: 143-152.

20. Mäkinen Y, Rantio-Lehtimäki A. Diurnal variation of airborne fungal spores in Turku, Finland, in 1974. Rep Aerobiol Lab Univ Turku. 1979; 1: 1-27.

21. Pérez CF, Gardiol JM, Paez MM. Comparison of intradiurnal variation of airborne pollen in Mar del Plata (Argentina). Part I. Non-arboretal pollen. Aerobiologia. 2001; 17: 151163. https://doi.org/10.1023/A:1010889203400.

22. Munoz Rodriguez AF, Palacios I, Molina R. Influence of meteorological parameters in hourly patterns of grass (Poaceae) pollen concentrations. Ann Agric Environ Med. 2010; 17: 87100 .

23. Pérez-Badia R, Rapp A, Vaquero C et al. Aerobiological study in east-central Iberian Peninsula: pollen diversity and dynamics for major taxa. Ann Agric Environ Med. 2001; 18: 99111.

24. Peel RG, Ørby PV, Skjøth CA et al. Seasonal variation in diurnal atmospheric grass pollen concentration profiles. Biogeosciences. 2014; 11: 821-832. https://doi.org/10.5194/bg11-821-2014.

25. Khan M, Perveen A, Qaiser M. Seasonal and diurnal variation of atmospheric fungal concentrations in Hyderabad, Tandojam-Sindh and the effects of climatic conditions. Pak J Bot. 2016; 48(4): 1657-1663.

26. Grewling $Ł$, Bogawski P, Smith M. Pollen nightmare: elevatedairborne pollen levels at night. Aerobiologia. 2016; 32(4): 725-728. https://doi.org/10.1007/s10453-016-9441-7.

27. Rantio-Lehtimäki A, Helander ML, Pessi AM. Circadian periodicityof airborne pollen and spores; significance of samplingheight. Aerobiologia. 1991; 7(2): 129-135. https://doi. org/10.1007/BF02270681.

28. Mar Trigo $M$, Recio $M$, Javier Toro $F$ et al. Intradiurnal fluctuations in airborne pollen in Málaga (S. Spain): A quantitative method. Grana. 1997; 36(1): 39-43. https://doi. org/10.1080/00173139709362588.

29. Norris-Hill J. The diurnal variation of Poaceae pollen concentrations in a rural area. Grana. 1999; 38(5): 301-305. https://doi.org/10.1080/001731300750044528.

30. Alwadie HM. Pollen Concentration in the Atmosphere of Abha City, Saudi Arabia and its Relationship with Meteorological Parameters. J Appl Sci. 2008; 8(5): 842-847. https:// doi.org/10.3923/jas.2008.842.847.
31. Veriankaitè L, Šaulienè I, Bukantis A. Evaluation of meteorological parameters influence upon pollen spread in the atmosphere. Journal of Environ Eng Landsc 2011; 19(1): 5-11. https://doi.org/10.3846/16486897.2011.557252.

32. Puc M. Influence of meteorological parameters and air pollution on hourly fluctuation of birch (Betula L.) and ash (Fraxinus L.) airborne pollen. Ann Agric Environ Med. 2012, 19(4): 660-665.

33. Ščevková J, Kováč J. First fungal spore calendar for the atmosphere of Bratislava, Slovakia. Aerobiologia. 2019, 35: 343-356. https://doi.org/10.1007/s10453-019-09564-4.

34. Hasnain SM. Influence of meteorological factors on the air spora. Grana. 1993; 32: 184-188. https://doi. org/10.1080/00173139309428955.

35. Oliveira M, Ribeiro H, Delgado JL et al. The effects of meteorological factors on airborne fungal spore concentration in two areas differing in urbanisation level. Int. Journal of Biometeorol. 2009; 53: 61-73. https://doi.org/10.1007/s00484008-0191-2.

36. Ianovici N. Relation between Poaceae pollen concentrations and meteorological factors during 2000-2010 in Timisoara, Romania. Acta Agrobotanica. 2015; 68(4): 373-381. https:// doi.org/10.5586/aa.2015.033.

37. Fang Y, Ma C, Bunting J et al. Airborne pollen concentration in Nanjing, Eastern China, and its relationship with meteorological factors. J Geophys Res Atmos. 2018; 10: 842-856. https://doi.org/10.1029/2018JD029026.

38. Comtois P, Fernández-González D, Valencia-Barrera RM et. al. Pollen content study of the lower atmosphere in León (Spain) by use of a tethered balloon. Aerobiologia. 2000; 16: 187-191. https://doi.org/10.1023/A:1007685513925.

39. Khattab A, Levetin E. Effect of sampling height on the concentration of airborne fungal spores. Ann Allergy Asthma Immunol. 2008; 101: 529-534. https://doi.org/10.1016/S10811206(10)60293-1.

40. Damialis A, Kaimakamis E, Konoglou M et al. Estimating the abundance of airborne pollen and fungal spores at variable elevations using an aircraft: how high can they fly? Sci Rep. 2017; 7(44535): 1. https://doi.org/10.1038/srep44535.

41. Galán C, Alcázar-Teno P, Domínguez-Vilches E et al. Airborne pollen grain concentrations at two different heights. Aerobiologia. 1995; 11(2): 105-109. https://doi.org/10.1007/ BF02738275.

42. Chakraborty P, Gupta-Bhattacharya S, Chowdhury I et al. Differences in concentrations of allergenic pollens and spores at different heights on an agricultural farm in west Bengal, India. Ann Agric Environ Med. 2001; 8(2): 123-130.

43. Atluri J, Verma KV, Reddi CS. Distribution of fungal spores within and above a crop of rice. Proc Indian Acad Sci. 1998; 98: 25-30. https://doi.org/10.1007/BF03053364. 
44. Rizzi-Longo L, Pizzulin-Sauli M, Stravisi F et al. Airborne pollen calendar for Trieste (Italy), 1990-2004. Grana. 2007; 46, 98-109. https://doi.org/10.1080/00173130701302826.

45. Ščevková J, Dušička J, Chrenova J et al. Annual pollen spectrum variations in the air of Bratislava (Slovakia): Years 2002-2009. Aerobiologia. 2010; 26(4): 277-287. https://doi. org/10.1007/s10453-010-9163-1.

46. Alcázar P, Galán C, Cariñanos P et al. Effect of sampling height and climatic conditions in aerobiological studies. I Investig Allergol Clin Immunol. 1999; 9(3): 253-261.

ORCID

K. Dąbrowska-Zapart - ID - http://orcid.org/ 0000-0002-8976-7739

T. Niedźwiedź - ID - http://orcid.org/0000-0003-0004-9501

Authors' contributions: Dąbrowska-Zapart K.: aerobiological data Sosnowiec, work concept, writing a manuscript, literature review, proofreading;
Niedźwiedź T.: meteorological data, proofreading in terms of climatology. Conflict of interests: The authors declare that they have no competing interests. Financial support: Research supported financially by the University of Silesia in Katowice. Ethics: The contents presented in this paper are compatible with the rules the Declaration of Helsinki, EU directives and standardized requirements for medical journals.

Copyright: (C) Medical Education sp. z 0.0. This is an Open Access article distributed under the terms of the Attribution-NonCommercial 4.0 International (CC BY-NC 4.0). License (https://creativecommons.org/licenses/by-nc/4.0/), allowing third parties to copy and redistribute the material in any medium or format and to remix, transform, and build upon the material, provided the original work is properly cited and states its license.

\section{Corresponding author:}

\section{Katarzyna Dąbrowska-Zapart, PhD}

Faculty of Natural Sciences, Institute of Earth Sciences, University of Silesia in Katowice 41-200 Sosnowiec, Będzińska 60 tel.: (32) 368-94-77

e-mail: katarzyna.dabrowska-zapart@us.edu.pl 